\title{
Baton Rouge (Louisiana): On the Importance of Thematic Cartography for 'Neopragmatic Horizontal Geography'
}

\author{
Olaf Kühne $^{1} \cdot$ Corinna Jenal $^{1}$ (D)
}

Received: 28 July 2020 / Accepted: 25 September 2020 / Published online: 16 October 2020

(c) The Author(s) 2020

\begin{abstract}
The presented contribution is based on the testing of a 'neopragmatic' access to spaces in the context of horizontal geography using the case study of Baton Rouge, Louisiana (USA). In this approach, the focus is less on the theoretical framing or the detailed development of community development, but rather on the importance of thematic cartography in the neopragmatic approach of regional geography. The neopragmatic approach prioritizes the multi-perspective study of spatial constellations over theoretical 'purity' and methodological clarity. The investigation is 'horizontally' oriented and is characterized by the constructivist framed synthesis of research results from different disciplines (e.g., on economic or structural development).
\end{abstract}

Keywords Baton Rouge $\cdot$ Thematic cartography $\cdot$ Neopragmatism $\cdot$ Horizontal geography $\cdot$ Louisiana $\cdot$ Cartodiagram

\section{Zusammenfassung}

Der vorliegende Beitrag basiert auf der Erprobung eines ,neopragmatischen ‘ Zugriffs auf Räume im Kontext horizontaler Geographien am Fallbeispiel Baton Rouge (USA). In dieser Annäherung stehen weniger die theoretische Rahmung oder die detaillierte Entwicklung der Siedlungsentwicklung im Vordergrund, sondern die Bedeutung thematischer Kartographie in der neopragmatischen regionalgeographischen Befassung. Dabei priorisiert der neopragmatische Zugriff eine perspektivenvielfältige Untersuchung räumlicher Konstellationen gegenüber theoretischer ,Reinheit " und methodischer Eindeutigkeit. In diesem Rahmen erfolgt eine ,horizontal ' ausgerichtete Untersuchung, die durch die konstruktivistisch gerahmte Synthese unterschiedlicher sektoraler Forschungsergebnisse (etwa zur ökonomischen oder baulichen Entwicklung) geprägt ist.

Schlüsselwörter Baton Rouge $\cdot$ Thematische Kartographie $\cdot$ Neopragmatismus · Horizontale Geographien · Louisiana · Kartodiagramm

\section{Introduction}

Baton Rouge, the capital of the state of Louisiana, is not a focus of public or professional attention, although Baton Rouge, more than most cities in the United States, has to cope with social, economic, and political contrasts, ecological challenges and is characterized by intensive political

The paper shows the possibilities of thematic cartography for the analysis and presentation of results for 'neopragmatic horizontal geographies'.

Corinna Jenal

corinna.jenal@uni-tuebingen.de

1 Geography, Urban and Regional Development, Eberhard Karls University Tübingen, Tübingen, Germany change: Baton Rouge "having flown under ten flags" (Armstrong 2010, S. 9), "the flags of France, England, Spain, the independent Republic of West Florida, the United States and the Confederate States of America were flown over it, some of them more than once" (Gleason und Brockway 1991, vii). In combination with a manageable size of around 230,000 inhabitants currently, Baton Rouge will thus become an ideal location for testing innovative regional geographic approaches.

The present paper is based on such a test of a 'neopragmatic' approach to Baton Rouge (Kühne und Jenal, 2020a). The focus is less on theoretical framing or the detailed development of community development than on the importance of thematic cartography in the neopragmatic regional geography study of Baton Rouge. (Neo)pragmatic approaches to spatial aspects have been discussed in various publications 
in the recent past beyond their testing in Baton Rouge (e.g., in Chilla et al. 2015; Eckardt 2014; Kühne 2018b, 2019b, 2020; Steiner 2014a). In short, this approach prioritizes a multi-perspective investigation of spatial constellations over theoretical 'purity' and methodological clarity. The basic constructional character of the representations-including the cartography-remains cognizant as well as the (potentially) manipulative aspect of (especially pictorial) representations (Crampton und Krygier 2005; Glasze 2014; Harley 2002). This is a 'horizontally' oriented study, which is characterized by the constructivist framed synthesis of different sectoral research results (for example, on economic or structural development) (in detail: Kühne 2018b; for the individual basic theoretical perspectives, see: Kühne 2019a).

Baton Rouge has been the subject of a systematic geographical investigation only once: in 1963, a German-language dissertation (Brill 1963) in which the spatio-temporal development of the community was described and analyzed in the style of traditional geography. This forms a valuable basis for comparison with current investigations, especially considering the cartographic representation of spatial distributions is a major part of the work. More recent scientific studies on Baton Rouge are strongly thematic in focused (among many: Antipova 2010; Brian 2003; Burby 2000; Richard 2006; Speights-Binet 2004) or are strongly linearhistorical and not spatial-historical (like Gleason und Brockway 1991; Rodrigue und Phillips 2008; Ruffin 2006).

The present essay first deals with the basic features of neopragmatic regional geography, and then introduces spatial-historical developments in Baton Rouge and then deals with the significance of thematic-cartographic access to space against the background of neopragmatic theoretical considerations.

\section{The Neopragmatic Horizontal Geography: Some Basic Features}

The category of the 'horizontal geographies' as a collective category for spatially integrating observations, in comparison to 'traditional' vertical geographies with specified focus, expands the theoretical perspectives. Framed in a constructivist manner, results obtained from a positivist perspective are made available and the view, thus broadening the view of regional context. The neopragmatic approach continues the tradition of pragmatism, which goes back to philosophers such as William James, Charles S. Peirce, and John Dewey, and has had a major influence on the Chicago School. They do, however, extend it by a (meta)theoretical dimension. Pragmatism focuses on the effects of action, in that meanings and truths should determine action, not moral principles or grand theories. Usability in certain concrete contexts thus becomes the touchstone, not consistency to principles (Joas
1988; Schubert et al. 2010; Steiner 2014a, b). Correspondingly, in pragmatism 'truth', 'theory', 'practice', etc., are not thought separately, but form "a unity mediated in the process of experience" (Steiner 2014a, S. 258).

'Neopragmatism' is discussed in philosophy, associated particularly with Rorty $(1982,1991)$ and Putnam (1995). This approach recognizes pluralistic views of the world as well as contingency and provides a framework for synthesizing the different aspects of space and landscape. Furthermore, neopragmatism is normatively oriented towards openended, democratic negotiation processes (see more in detail: Hildebrand 2003, 2005; Warms und Schroeder 1999). Pluralism and openness are correspondingly the basic features of the approach presented here: the neopragmatic approach of 'horizontal geography' (Kühne 2018a, b) creates a differentiated picture of complex research objects (such as, in this instance, a community with its various regional-to-global references) by means of 'theoretical' and also empirical 'triangulation', whereby (partial) contradictions between theoretical approaches or the relationship between the various justifiably chosen theories and the equally chosen empirical methods are also accepted. In this respect, a basic social constructivist perspective can be combined with methods of quantitative social research, although these are more likely to be attributed to a positivist world view (Kühne 2018a). A further difference to 'classical' theoretical approaches that strive for 'purity' is the potential for interdisciplinary and, similarly, transdisciplinarity: while 'explanation of the world' (as in the context of positivism) is the main goal of classical theories, neopragmatic approaches can not only generate cross-disciplinary perspectives, but can also be used to generate guidelines for political or administrative practice (Berr et al. 2019; Chilla et al. 2015, 2016; Weber et al. 2016). The choice of theoretical approaches and empirical methods must be contextualized in terms of claims to validity and justified in terms of thematic appropriateness.

\section{Baton Rouge: An Outline of Spatial-Historical Developments}

The name 'Baton Rouge' is a toponym that goes back to an expedition in 1699, which found a red stake (others say it was a large cypress) in the vicinity of the present town. The development of the settlement, supported by European immigrants, began in 1721 with the farming of the D'Artaguette brothers, but remained modest until the turn of the eighteenth and nineteenth centuries, regardless of the nationality of the colonial power (France, Spain, and England; Carleton 1981; Rodrigue und Phillips 2011). Baton Rouge received a development boost with the integration of Louisiana into the United States, the liberal economic order of intensified trade and agriculture, and in 1850, 
Baton Rouge became the seat of the Louisiana Legislature, which meant not only a gain in political importance but also increasing immigration (Brill 1963; Douglas 1955). The American Civil War, in turn, meant a turning point: trade collapsed, with the liberation of slaves the social and economic conditions changed fundamentally, and Baton Rouge temporarily lost its political significance. The reason for this was the partial destruction of the Old Louisiana State Capitol through acts of war and the reconstruction era, in which the former Confederate States were deprived of their political self-determination. The Constitution of 1879 established Baton Rouge (to this day) as the capitol of Louisiana and the growth of the city at the end of the nineteenth century made the construction and operation of a tramway lucrative (now long since shut down); Carleton 1981; Draughon Jr. 1998; Rodrigue und Phillips 2011; Woodward 1981).

Baton Rouge received a significant boost in development between 1909 (when the petrochemical industry was established in Baton Rouge) and the Second World War (when the petrochemical industry boomed due to the war). The city received a further pole of development with the establishment of the campus of the Louisiana State University in the southern section of the city and also the public administration structures were developed-Baton Rouge developed into a 'tripolar metropolis' (Kühne und Jenal 2020a), a paradigm that persists to this day (Burby 2000; Carleton 1981; Rodrigue und Phillips 2011; Ruffin 2006). The postwar history of Baton Rouge was strongly influenced economically by the impact oil price values-directly by the petrochemical industry, indirectly by the state's tax revenues from this industry. Also ecologically, the strong importance of the petrochemical industry had side effects (especially in air pollution), and in terms of transport geography, local public transport (and long-distance transport) was marginalized in favor of automobile transport-combined with extensive suburbanization (Kühne et al. 2020; Kühne und Jenal 2020a, b).

Baton Rouge is-in comparison to other metropolitan regions in the United States as well as the Southern Statesan extreme form of urbanization: the so-called Bartholomew Report (Bartholomew 1945-1948) came to the conclusion at the end of the 1940s that the development of Baton Rouge was characterized almost exclusively by economic calculation with minimal political-administrative influence (which was also reflected in the low level of development of the technical and social infrastructure), a state of affairs that has hardly changed to this day. In this respect, Baton Rouge represents a metropolitan region that-almost ideally-leaves spatial development to economic calculations-with corresponding consequences for the unequal distribution of life chances (in the sense of Ralf Dahrendorf 1979; in summary: Kühne and Leonardi 2020): Baton Rouge is one of the most socially fragmented cities in the United States. In Louisiana, for example, Baton Rouge contains the area with the highest HDI (Human Development Index; south of Florida Street/ Boulevard) and the area with the lowest HDI (north of it; Burd-Sharps et al. 2009).

In the following, essential aspects of the spatial development of Baton Rouge are presented in cartographic form.

\section{The Importance of Thematic-Cartographic Accesses}

In comparison to the presentation of the study on spatial development and differentiation in and around Baton Rouge, which results in the synthesis cartogram (Fig. 1) (Kühne und Jenal 2020a), we will begin our considerations about the cartographic preparation of the study with this initial synthesis cartogram, and then, using some cartographic representations as examples, we will demonstrate certain developments and distributions.

Starting from the obligatory evaluation of the available scientific literature, the studies on which the synthesis cartogram is based combined different theoretical and empirical approaches-following the neopragmatic approach. From a social constructivist perspective, qualitative methods of empirical social research (interviews, media content research, here the analysis of the contents of the Washington Post, of Google Search hits, song lyrics, and YouTube videos) were used to explore the different patterns of interpretation and evaluation of Baton Rouge (and its spatial contextualization), such as the external ascriptions and the answers generated in Baton Rouge (northeast angle). Other syntheses, in turn, are based on 'hard' data collected according to positivist theoretical framing, such as population densities, building heights, land use, the distribution of high schools of different jurisdiction, etc., after cartographic processing and was subsequently discussed with colleagues and residents of Baton Rouge and slightly revised. An example is the "Triangle of diminished life chances" in the center of the map, the background of which will be discussed in this article. The access to spatial arrangements is characterized by atmospheric references besides 'spatial facts' and symbolic attributions. These experiences-gained on a phenomenological basis-are reflected, not least, in the representation and characterization of linear structures (such as Florida Street/Boulevard), Plank Road, and Government Street. The synthesis of the secession (especially in the case of St. George in the south of Baton Rouge) lies next to a discourse theoretical approach, in which we deal with the struggle for hegemonic interpretations for the incorporation of St. George as well as on an investigation of the distribution of public and private high schools (which suggests that the reason for the secessionists to want to create a better public school system can be evaluated at least critically, since 


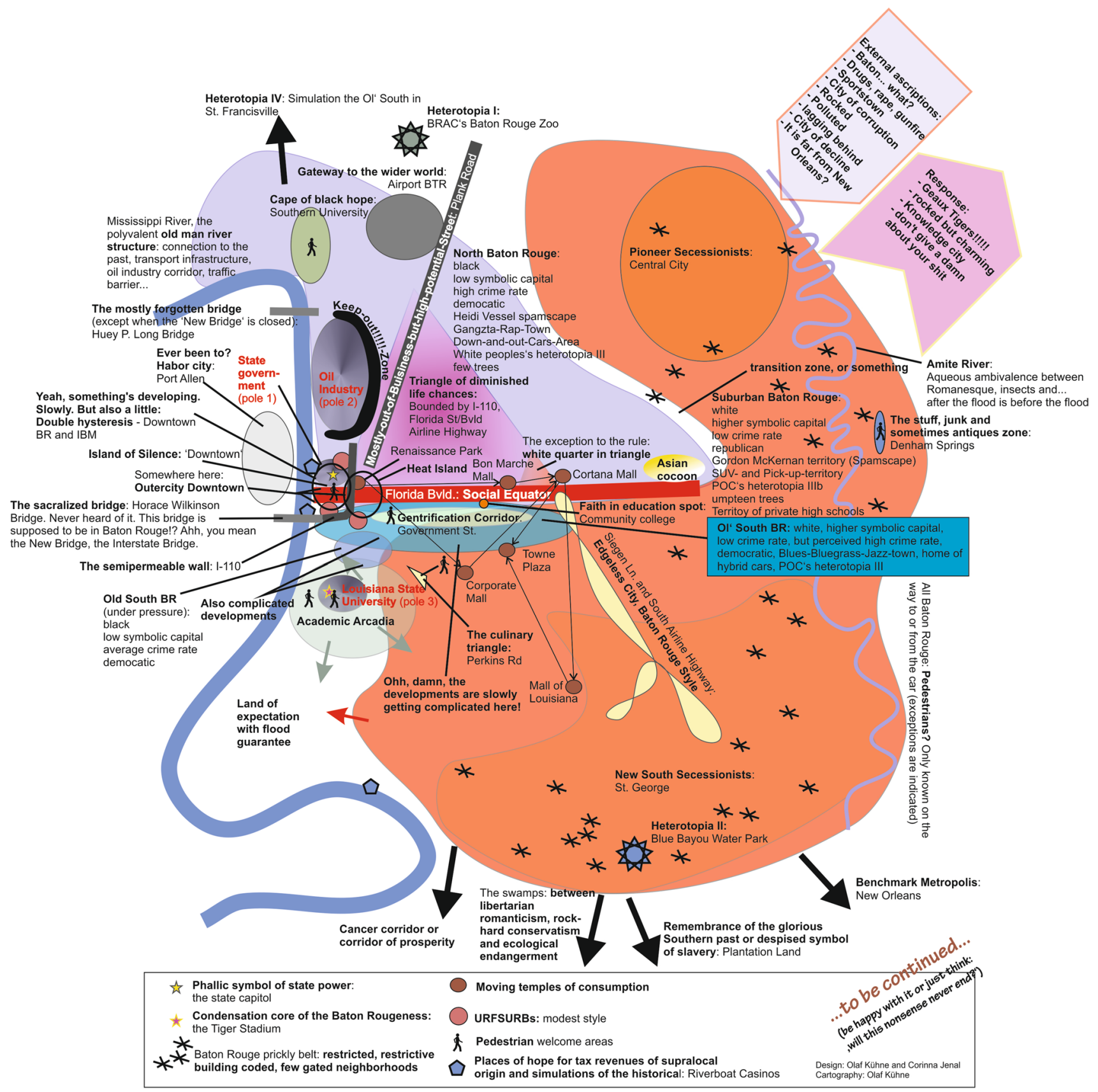

Fig. 1 Synthesis cartogram of the results of the neopragmatic study of horizontal geographies in and around Baton Rouge. The term 'synthetic cartogram' is derived from the fact that it is a cartographic representation, and that area, line, and point statements are only shown in similarity of position. To make this clear, not only a mixture of

here, in the prosperous and white South, public schools are scarce and the argument of tax avoidance for a public school system seems more valid).

The synthesis cartogram, in turn, can be interpreted as a construction of spatial phenomena in and around Baton Rouge- selectively even beyond - secured by triangulations. To clarify the constructional character of the interpretations spelling and abstract signatures was chosen, but also a scale and a north arrow were omitted. The word part 'synthesis' refers to the fact that different statements obtained from the different empirical investigation parts were subjected to an abstracting summary. (Source: Kühne und Jenal 2020a)

(and evaluations) we have made, we have chosen the form of a cartogram, whose elements are combined by similarity of location, abstracted forms (bubbles), and their combination with conversation generated signatures (such as pedestrians). Finally, the cartogram is based on studies that have both a technical (geography, sociology, and political science) déformation professionnelle of the professional research team 
on the results and their presentation, a certain normative perspective (that of maximizing life chances in the sense of Dahrendorf 1979), but also its regional socialization in Central Europe-with the consequence that developments, such as the downtown area of Baton Rouge, deviate from the views of American colleagues. We will deal with these downtown developments and their entry into the synthesis cartogram in the following.

The change in land use in downtown Baton Rouge between the 1959 survey (Fig. 2; database: Brill 1963) and the survey year 2019 (Fig. 3) is profound: the importance of supplying the population with goods has, with a few

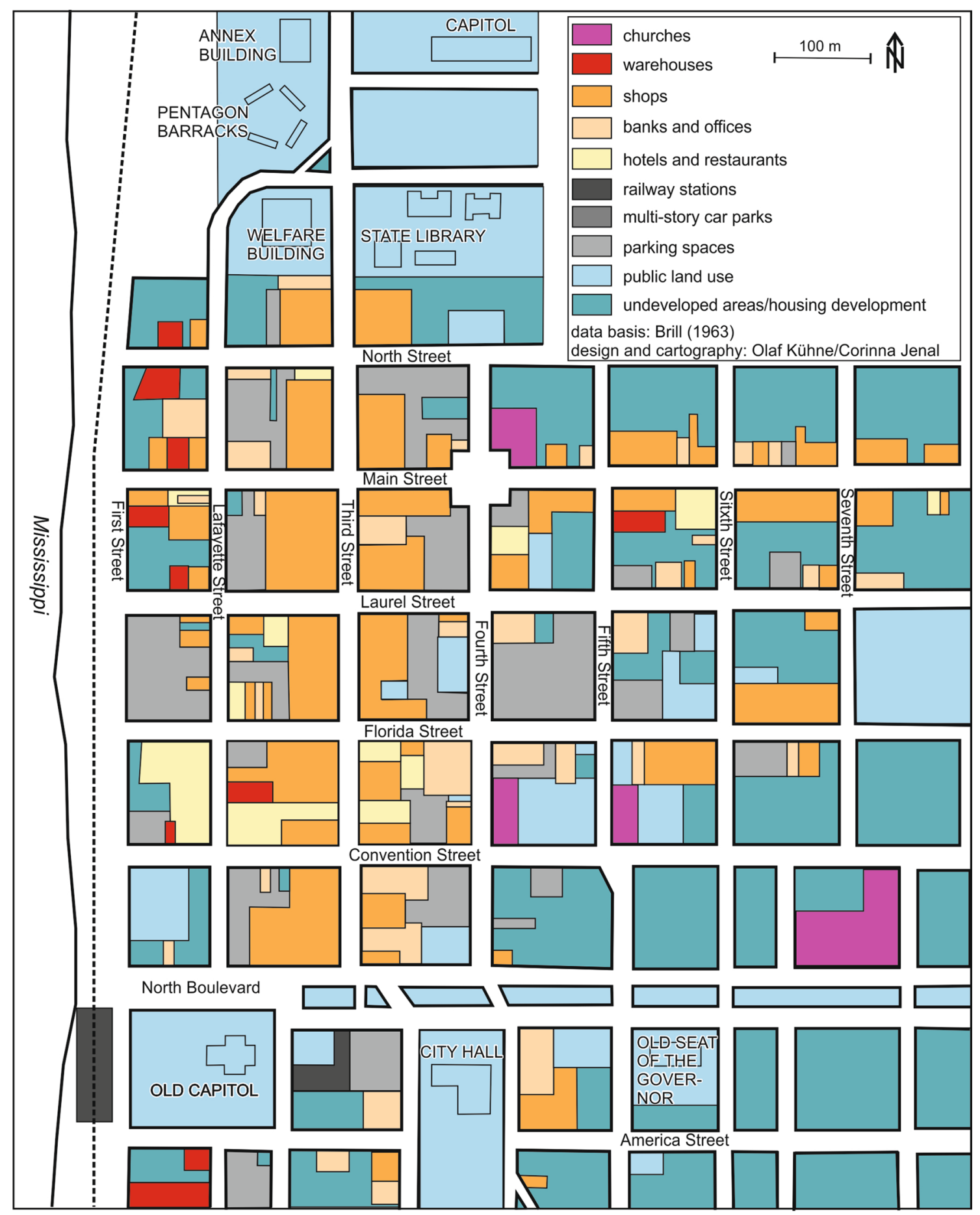

Fig. 2 Land uses in the downtown area of Baton Rouge 1959. (Source: Kühne und Jenal 2020a) 


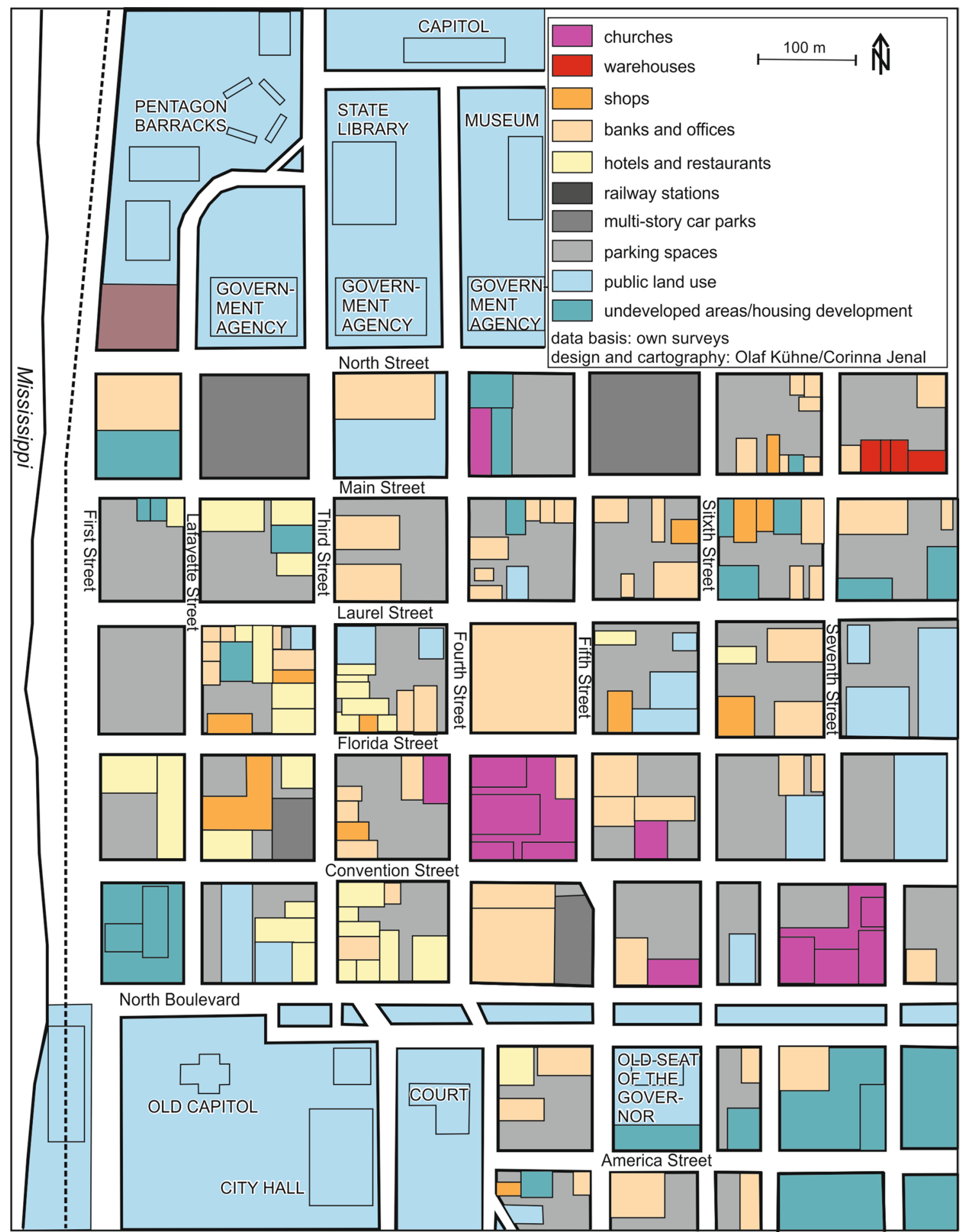

Fig. 3 Land uses in the downtown area of Baton Rouge 2019. (Source: Kühne und Jenal 2020a)

exceptions, disappeared (the supply function has now been taken over by shopping malls, whose first and second generations, from the 1970s and 1980s, have since been abandoned). The downtown area has undergone a transformation into a business center, flanked by an expansion in the use of space for public administration and the complete loss of importance of rail-bound passenger transport. Following the positivist perspective of this part of the study, the cartographic form of presentation was also chosen: an analytical thematic map in single-layered representation with colored 
areas, with clear border lines, which convey a high degree of fidelity of the represented land uses.

The fundamental functional change of the downtown of Baton Rouge is not only an expression of a global phenomenon that is taking place especially in the cities throughout the United States, it is also an expression of a specific feature of Baton Rouge. The city was initially built flood-safe on the terrace of the Mississippi River. The port (at Port Allen), which is now located on the other side of the river, provided a major impetus for development. The city of Baton Rouge has been developing eastward since the nineteenth century, which is why the downtown area has assumed an increasingly eccentric spatial position, combined with compared to cities with centric downtown positions long daily commuting. The loss of the commercial function (especially regarding retail), in turn, is reflected in a low presence of people, but also traffic (with the exception of rush hour traffic). The resulting "island of silence" (Fig. 1, center left) is most pronounced where the port used to generate its specific soundscapes. The noise landscape, which is now almost exclusively generated by road traffic and can be experienced phenomenologically, can also be operationalized empirically by measuring sound pressure in the positivist tradition of thought and processed graphically with the aid of a map diagram (Fig. 4), whereby the regular pattern of the road course accommodates this type of representation (more on this form of cartography: Edler et al. 2019a; on phenomenological approaches to the Baton Rouge region: McEwen 2014).

The importance of the petrochemical industry as a pole of development (see, for example, also Fig. 1, north of downtown) was already evident in the context of the historical outline of the city's development. It provided (and continues to provide) jobs and tax revenues, but is also largely responsible for the high air pollution in Baton Rouge compared to other cities of comparable size (Burby 2000; Colten 2000; Hardy 2019). The ambivalence and importance of the petrochemical industry for Baton Rouge became particularly clear following an explosion at the EXXON plant on December 23, 1989, which caused massive damage in the surrounding residential areas. These homes had been built right up to the plant site-as a result of a virtually non-existent spatial community planning. In the years that followed, EXXON resorted to 'private-law' regional planning and acquired the real estate east of its plant site and demolished the buildings standing on it (Fig. 5). This becomes clear in the reduced cartographic representation of the figure-ground diagram, here supplemented by the streets. This addition-especially when compared to the area east of the Interstate 110-highlights the divergence between existing infrastructure and buildings.

\section{Conclusion}

The present contribution was able to illustrate the importance that thematic cartography can have for a 'neopragmatic horizontal geography'. It can also be described as 'postdeconstructivist', in that it accepts the constructional character of maps in particular, and (complex) spatial knowledge in general, and is aware of the (potentially) manipulative representation of graphical representations (not only maps). Additionally, it is also endeavoring to avoid gross one-sidedness through the different triangulations and, in the type of graphical representation, also represents the quality of the underlying data (e.g., in the case of synthetic cartograms with a high interpretative content, not to give the appearance of being directly fact-based through exact representations). Furthermore, the persistence in deconstructing cartographic representations, in particular, and graphic representations, in general, closes the access to complex spatial phenomena. In this respect, the function of thematic maps in 'neopragmatic horizontal geography' is not limited to the representation of these very phenomena, but rather represents a medium for the analysis of such phenomena, which can ultimately be synthesized and correlated to each other and to phenomena and interpretations that are not represented or cannot be represented cartographically. Besides 2D representations, the possibilities of modern immersive and interactive 3D visualizations in virtual reality for the presentation or even discovery of a historically complex city or even a US state

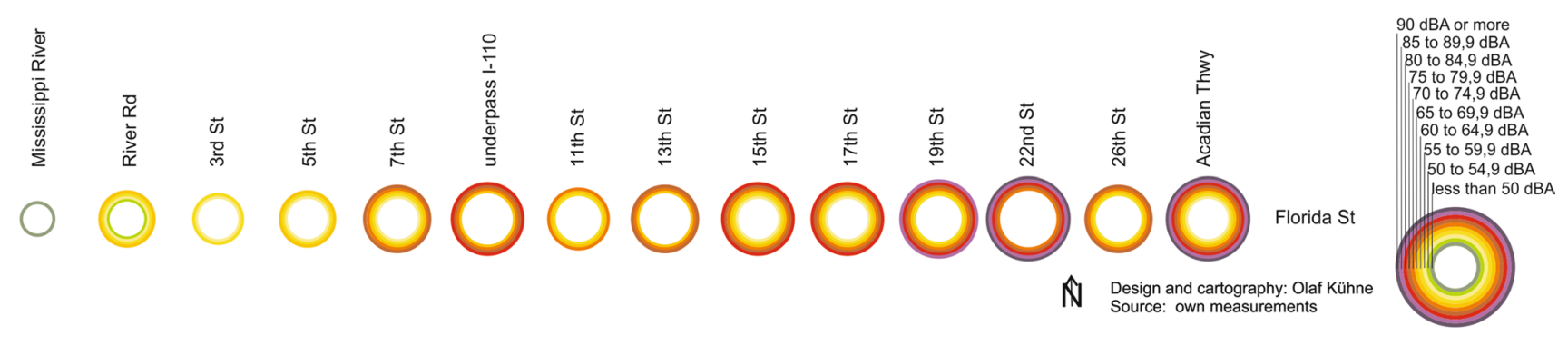

Fig. 4 Cartodiagram showing the minimum and maximum measured sound pressure levels at intersections along Florida Street (three traffic light cycles each) from the Mississippi to the Acadian Thruway as a central traffic axis to downtown and to measure the noise emissions; the measurements were carried out on a September day between 1:15 and 2:30 pm. (Source: Kühne und Jenal 2020a) 


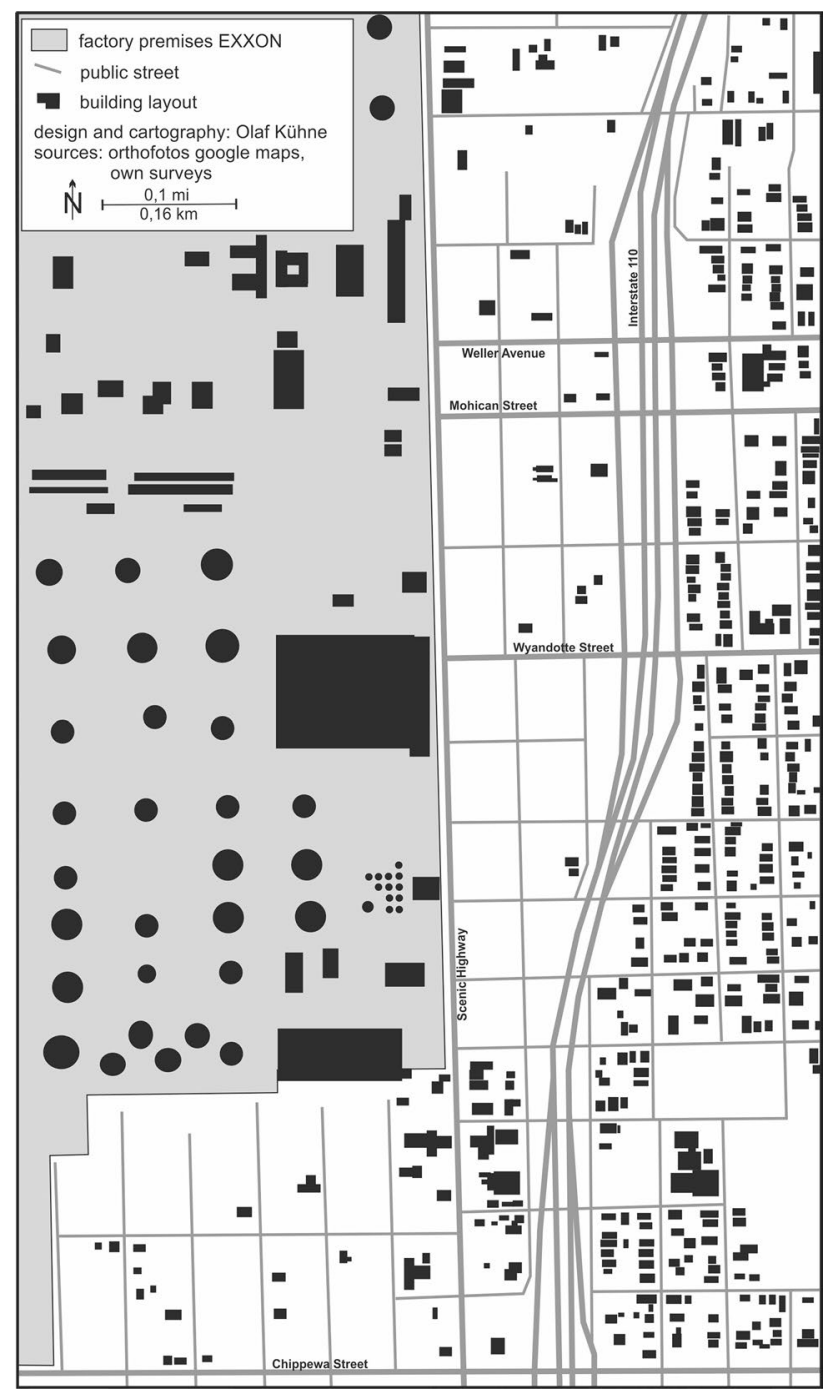

Fig. 5 Extended figure-ground diagram of the eastern EXXON site and its surroundings. The figure-ground diagram is a cartographic form of representation that is widely used in urban planning. In addition to the usual limitation to the floor plan of buildings, streets have been added here to illustrate the discrepancy between the road network and the buildings resulting from the acquisition and demolition of real estate by EXXON following the explosion in 1989. (Source: Kühne und Jenal 2020a)

(Louisiana) (see, for example, also Edler et al. 2018a, b, 2019b; Hruby 2019; Kersten et al. 2018) represent an interesting extension of the approach. Here, the possibilities of combining topographic information with thematic content and even acoustic stimuli can be considerably expanded. This would result in a considerable extension of the occupation with 'horizontal geographies' in the direction of a broad transfer of interest-specific knowledge on the part of the users, but especially if access to technical requirements and usability is low threshold.

As with the combination of theories and methods in the neopragmatic access to spatiality in general, the use of cartographic representations and analyses also requires justification. The reflection of one's own ideological contextualization is also essential. In this form, thematic cartography becomes a central instrument for dealing with spatial complexities—and, not in the least, contingencies.

Funding Open Access funding enabled and organized by Projekt DEAL.

Open Access This article is licensed under a Creative Commons Attribution 4.0 International License, which permits use, sharing, adaptation, distribution and reproduction in any medium or format, as long as you give appropriate credit to the original author(s) and the source, provide a link to the Creative Commons licence, and indicate if changes were made. The images or other third party material in this article are included in the article's Creative Commons licence, unless indicated otherwise in a credit line to the material. If material is not included in the article's Creative Commons licence and your intended use is not permitted by statutory regulation or exceeds the permitted use, you will need to obtain permission directly from the copyright holder. To view a copy of this licence, visit http://creativecommons.org/licenses/by/4.0/.

\section{References}

Antipova, A. (2010): Land use, individual attributes, and travel behavior in Baton Rouge, Louisiana. Online verfügbar unter https:// digitalcommons.lsu.edu/gradschool_dissertations/3450/. zuletzt geprüft am 13 June 2019

Armstrong AM (2010) Historic neighborhoods of Baton Rouge. The History Press, Charleston

Bartholomew H (1945-1948) The 25 year-Parish plan for metropolitan Baton Rouge: Louisiana. Eigenverlag, Baton Rouge

Berr K, Jenal C, Kühne O, Weber F (2019) Inter- und transdisziplinäre Landschaftsforschung. In: Kühne O, Weber F, Berr K, Jenal C (eds) Handbuch Landschaft. Springer VS, Wiesbaden, pp 165-180

Brian JL (2003) Relative costs of infill vs. suburban residential developments: a case study of the Greater Baton Rouge area. Online verfügbar unter https://digitalcommons.lsu.edu/gradschool_these s/1243/. zuletzt geprüft am 13 June 2019

Brill D (1963) Baton Rouge, LA: Aufstieg, Funktionen und Gestalt einer jungen Großstadt des neuen Industriegebietes am unteren Mississippi. Selbstverlag des Geographischen Instituts der Universität Kiel, Kiel

Burby RJ (2000) Baton Rouge: the making (and breaking) of a petrochemical paradise. In: Colten CE (ed) Transforming New Orleans and its environs. Centuries of change. University of Pittsburgh Press, Pittsburgh, pp 160-177

Burd-Sharps S, Lewis K, Martins EB (2009) A portrait of Louisiana: Louisiana Human Development Report 2009. Online verfügbar unter https://mk0moaorgidkh7gsb4pe.kinstacdn.com/wp-conte nt/uploads/A_Portrait_of_Louisiana.pdf. zuletzt geprüft am 01 July 2019

Carleton MT (1981) River capital: an illustrated history of Baton Rouge. Windsor Publications Inc, Woodland Hills

Chilla T, Kühne O, Weber F, Weber F (2015) „Neopragmatische“ Argumente zur Vereinbarkeit von konzeptioneller Diskussion und Praxis der Regionalentwicklung. In: Kühne O, Weber F (eds) Bausteine der Regionalentwicklung. Springer VS, Wiesbaden, pp $13-24$

Chilla T, Kühne O, Neufeld M (2016) Regionalentwicklung. Ulmer, Stuttgart

Colten CE (2000) Too much of a good thing: industrial pollution in the lower Mississippi River. In: Colten CE (ed) Transforming New 
Orleans and its environs. Centuries of change. University of Pittsburgh Press, Pittsburgh, pp 141-159

Crampton J, Krygier J (2005) An introduction to critical cartography. ACME Int J Crit Geogr 4(1):11-33

Dahrendorf R (1979) Lebenschancen: Anläufe zur sozialen und politischen Theorie. Suhrkamp, Frankfurt (Main)

Douglas ML (1955) Some aspects of the social history of Baton Rouge from 1830 to 1850 . Eigenverlag, Baton Rouge

Draughon R Jr (1998) Down by the river: a history of the Baton Rouge Riverfront. US Army Corps of Engineers, New Orleans District, New Orleans

Eckardt F (2014) Stadtforschung: Gegenstand und Methoden. Springer VS, Wiesbaden

Edler D, Husar A, Keil J, Vetter M, Dickmann F (2018a) Virtual reality (VR) and open source software: a workflow for constructing an interactive cartographic VR environment to explore urban landscapes. KN J Cartogr Geogr Inf 68(1):5-13

Edler D, Kühne O, Jenal C, Vetter M, Dickmann F (2018b) Potenziale der Raumvisualisierung in virtual reality (VR) für die sozialkonstruktivistische Landschaftsforschung. Kartographische Nachrichten 68(5):245-254

Edler D, Kühne O, Keil J, Dickmann F (2019a) Audiovisual cartography: established and new multimedia approaches to represent soundscapes. KN J Cartogr Geogr Inf 69:5-17

Edler D, Keil J, Wiedenlübbert T, Sossna M, Kühne O, Dickmann F (2019b) Immersive VR experience of redeveloped post-industrial sites: the example of "Zeche Holland" in Bochum-Wattenscheid. KN J Cartogr Geogr Inf 38(3):1-18

Glasze G (2014) Sozialwissenschaftliche Kartographie-, GIS- und Geoweb-Forschung. Kartographische Nachrichten 64(3):123-129

Gleason DK, Brockway WR (1991) Baton Rouge: photographs and text. Louisiana State University Press, Baton Rouge

Hardy S (2019) Baton Rouge is compliant with federal air quality standards, but the city's air still has F rating. In: The Advocate. Online verfügbar unter https://www.theadvocate.com/baton_rouge /news/environment/article_d65ea634-7bf7-11e9-8f9c-b7dc8 76b1031.html. zuletzt geprüft am 22 July 2020

Harley BJ (2002) Deconstructing the map. In: Laxton P (ed) The new nature of maps. Essays in the history of cartography. John Hopkins University Press, Baltimore, pp 149-168

Hildebrand DL (2003) The neopragmatist turn. Southwest Philos Rev 19(1):79-88

Hildebrand DL (2005) Pragmatism, neopragmatism, and public administration. Adm Soc 37(3):345-359

Hruby F (2019) The sound of being there: audiovisual cartography with immersive virtual environments. KN J Cartogr Geogr Inf 69(1):19-28

Joas H (1988) Symbolischer Interaktionismus: von der Philosophie des Pragmatismus zu einer soziologischen Forschungstradition. Kölner Zeitschrift für Soziologie und Sozialpsychologie 40:417-446

Kersten TP, Deggim S, Tschirschwitz F, Lindstaedt M, Hinrichsen N (2018) Segeberg 1600-Eine Stadtrekonstruktion in virtual reality. Kartographische Nachrichten 68(4):183-191

Kühne O (2018a) Landschaft und Wandel: Zur Veränderlichkeit von Wahrnehmungen. Springer VS, Wiesbaden

Kühne O (2018b) Reboot „Regionale Geographie“—Ansätze einer neopragmatischen Rekonfiguration „horizontaler Geographien“. Berichte Geographie und Landeskunde 92(2):101-121

Kühne O (2019a) Landscape theories: a brief introduction. Springer VS, Wiesbaden

Kühne O (2019b) Sich abzeichnende theoretische Perspektiven für die Landschaftsforschung: Neopragmatismus, Akteur-NetzwerkTheorie und Assemblage-Theorie. In: Kühne O, Weber F, Berr $\mathrm{K}$, Jenal C (eds) Handbuch Landschaft. Springer VS, Wiesbaden, pp 153-162
Kühne O (2020) Landscape conflicts-a theoretical approach based on the three worlds theory of Karl Popper and the conflict theory of Ralf Dahrendorf, illustrated by the example of the energy system transformation in Germany. Sustainability 12(17):6772

Kühne O, Jenal C (2020a) Baton Rouge-the multivillage metropolis: a neopragmatic landscape biographical approach on spatial pastiches, hybridization, and differentiation. Springer VS, im Druck, Wiesbaden

Kühne O, Jenal C (2020b) Stadtlandhybride Prozesse in Baton Rouge: von der klassischen Downtown zur postmodernen Downtownsimulation. In: Duttmann R, Kühne O, Weber F (eds) Landschaft als Prozess. Springer VS, in diesem Band, Wiesbaden

Kühne O, Jenal C, Koegst L (2020) Postmoderne Siedlungsentwicklungen in Baton Rouge, Louisiana: Stadtlandhybridität und Raumpastiches zwischen Begrenzungen und Entgrenzungen. In: Weber F, Wille C, Caesar B, Hollstegge J (eds) Geographien der Grenzen. Räume - Ordnungen - Verflechtungen. Springer VS, im Erscheinen, Wiesbaden

Kühne O, Leonardi L (2020) Ralf Dahrendorf: Between social theory and political practice. Palgrave Macmillan, London

McEwen JW (2014) Sense of place, place attachment, and rootedness in four West Baton Rouge Parish, Louisiana Bars. Online verfügbar unter https://digitalcommons.lsu.edu/gradschool_dissertati ons/1500/. zuletzt geprüft am 13 June 2019

Putnam H (1995) Pragmatism: an open question. Blackwell Publishers, Cambridge

Richard MD (2006) Racial disparities, birth outcomes, and changing demographics of East Baton Rouge Parish, Louisiana. Online verfügbar unter https://digitalcommons.lsu.edu/gradschool_dissertati ons/1870/. zuletzt geprüft am 01 July 2019

Rodrigue SF, Phillips F (2008) Baton Rouge. Arcadia Publishing, Charleston

Rodrigue SF, Phillips F (2011) Historic Baton Rouge: an illustrated history. Historical Publishing Network, a division of Lammert Incorporated, San Antonio

Rorty R (1982) Consequences of pragmatism: essays: 1972-1980. University of Minnesota Press, Minneapolis

Rorty R (1991) Objectivity, relativism, and truth. Cambridge University Press, Cambridge

Ruffin TF (2006) Under Stately Oaks: a pictorial history of LSU. Louisiana State University Press, Baton Rouge

Schubert H-J, Joas H, Wenzel H (2010) Pragmatismus zur Einführung: Kreativität, Handlung, Deduktion, Induktion, Abduktion, Chicago School, Sozialreform, symbolische Interaktion. Junius, Hamburg

Speights-Binet J (2004) The road to redevelopment: New Urbanism, nostalgia, and the process of downtown revitalization in Baton Rouge, Louisiana. Online verfügbar unter https://digitalcommons.lsu.edu/ gradschool_dissertations/89/. zuletzt geprüft am 01 July 2019

Steiner C (2014a) Pragmatismus - Umwelt - Raum: Potenziale des Pragmatismus für eine transdisziplinäre Geographie der Mitwelt. Franz Steiner Verlag, Stuttgart

Steiner C (2014b) Von Interaktion zu Transaktion - Konsequenzen eines pragmatischen Mensch-Umwelt-Verständnisses für eine Geographie der Mitwelt. Geographica Helvetica 69(3):171-181

Warms CA, Schroeder CA (1999) Bridging the gulf between science and action: the "new fuzzies" of neopragmatism. Adv Nurs Sci 22(2): $1-10$

Weber F, Kühne O, Jenal C, Sanio T, Langer K, Igel M (2016) Analyse des öffentlichen Diskurses zu gesundheitlichen Auswirkungen von Hochspannungsleitungen - Handlungsempfehlungen für die strahlenschutzbezogene Kommunikation beim Stromnetzausbau: Ressortforschungsbericht. Online verfügbar unter https:// doris.bfs.de/jspui/bitstream/urn:nbn:de:0221-2016050414038/3/ BfS_2016_3614S80008.pdf. zuletzt geprüft am 17 Oct 2018

Woodward CV (1981) Origins of the New South, 1877-1913: a history of the South. LSU Press, Baton Rouge 